DOI: http://doi.org/10.31617/k.knute.2019-03-19.48

\title{
ПРАВИЛЬНЕ ІНТОНУВАННЯ ПУБЛІЧНИХ ВИСТУПІВ ЯК ОСНОВА КОМУНІКАЦІЇ
}

\author{
Кучкін М. С. \\ студент 4 курсу \\ Файвішенко Д. С. \\ к.е.н., доцент \\ кафедра журналістики та реклами \\ Київський національний торговельно-економічний університет, \\ Украӥна
}

Ключові слова: публічний виступ, інтоначія, комунікація, публіка, риторика, темп промови, тон промови, оратор.

Keywords: public projection, intonation, communication, public, rhetoric, rate of speech, voice tone, speaker.

Публічний виступ - не просто публіцистичний твір, написаний та озвучений автором, а текст - призначений для виголошення перед публікою з метою іiі переконання, одержання підтримки й зміцнення авторитету виступаючого. Саме тому, виступ перед людьми повинен бути не тільки змістовним, доречним, переконливим, а й виразним. В основі усної виразності лежить правильне інтонування. За словами Ольги Олійник, «логіко-інтонаційна виразність мови полягає у вмінні «оратора чітко, повно, без перекручень донести до слухачів зміст промови, ї̈ основної ідеї».

Не секрет, що далеко не всі мовці вільно почуваються перед аудиторією, а тому навіть бездоганно написаний текст не можуть озвучити так, щоб донести його зміст та ідеї до слухачів. Ще менший емоційний вплив такого виступу. Традиційно правильно інтонувати навчають майбутніх акторів, юристів, журналістів, політологів. Мистецтво інтонування давно стало частиною науки риторики.

Саме в царині риторики доведено, що манера виголошення промови, має вирішальне значення на досягнення мети виступу. В риториці розроблено систему прийомів і правил виголошення промов, які об'єднано під терміном «акція». В основі акційної вправності, як доводить Іржі Томан, лежитть уміння вибрати темп і тон виступу. Найбільш спрятливим темпом для сприйняття аудиторією змісту промови є приблизно темп в 100-120 слів на хвилину. Правда, виявляється, що темп мовлення не однаковий для носіїв різних мов. Для естонців та фінів від близько 100 слів на хвилину, для українців - 
близько 120, а в англійців темп має амплітуду від 120 до 150 слів. Якщо його не дотримуватись, тобто якщо оратор говорить дуже швидко або повільно, слухачі втрачають стрижень розмови, а незабаром й інтерес до неї. Треба пам'ятати, що найбільш важлива інформація повинна виділятися повільним темпом, а другорядна - в пришвидшеному темпі.

Темп - це складова частина інтонайї. У мовознавсті інтонація розглядається як складна єдність висоти, сили темпу і тембру мовлення, які $є$ засобом організації словесного вираження, висловлювання й емоційно-вольових показників виразності. Крім того, що інтонаційними засобами встановлюються комунікативні значення слів у реченні, відбувається членування, здійснюється його внутнрішня єдність. Кожне речення у мовленні має свій інтонаційний малюнок, який відображає думку мовця та емоційно-вольове ставлення його до змісту висловлення. Наприклад, речення одного з творів Олеся Гончара Людство не усвідомить себе як єдине иіле - не буде йому добра має особливий інтонаційний малюнок, який має вершини на словах не усвідомить, єдине иџіле, не буде добра, які треба вимовляти 3 логічним наголосом, дещо уповільненому темпі, а на місці тире робити паузу зі зламаною інтонацією «підвищення - зниження».

Вправний оратор повинен володіти мистецтвом інтонування. Оратор мусить вправно користуватися інтонаціями. Монотонне проголошення промови стомлює. Неприпустима «нерішуча» інтонація. Якщо вона не відповідає змісту, то слухачі не засвоюють $40 \%$ промови. Відомий оратор Анатолій Коні висав: «Перед кожним виступом слід подумки осягнути план промови, так би мовити, упорядкувати свої матеріали. Коли лектор усвідомоює все те, що має говорити, це надає йому бадьорості, певності та заспокоює...».

Публічні виступи здійснюються у різних ситуаціях, мають різну мету, проводяться в різних аудиторіях. Цього не можна не враховувати, готуючись до зустрічі 3 публікою. Фахівці 3 ораторського мистецтва виокремлюють два основні різновиди поблічних виступів: звичайний публічний виступ і мітинговий. Вони відрізняються між собою передусім за особливостями інтонації.

Публічний виступ досягне мети тоді, коли оратор зуміє правльно підібрати тон цього виступу. Існують кілька різновидів тону: прятельський, агресивний, театральний, повчальний, урочистий, діловий та інші. Дведено, що краще всього аудиторія сприймає промови виголошені миролюбним, діловим та розмовним тоном, в основі яких лежить і відповідна інтонація. 


\title{
Список використаних джерел
}

1. Олійник О. Ораторське мистецтво юриста / О. Олійник. - Київ, 2009. - 209 c.

2. Томан I. Мистецтво говорити / I. Томан. - Київ, 1986. - 218 с.

\section{DOI: http://doi.org/10.31617/k.knute.2019-03-19.49 ОСОБЛИВОСТІ РЕКЛАМИ В ТУРИЗМІ}

\author{
Литвин О. В. \\ викладач \\ Кирилюк I. М. \\ к.е.н., доцент \\ кафедра технологій та організації туризму і готельно- \\ ресторанної справи \\ Уманський державний педагогічний університет \\ ім. Павла Тичини, Украӥна
}

Ключові слова: туризм, реклама, туристична реклама, інтернетреклама, нетрадиційна реклама, спеціалізована туристична реклама.

Keywords: tourism, advertising, tourist advertising, internet-advertising, untraditional advertising, the tourist advertising is specialized.

Реклама являється невід'ємною складовою ведення туристичного бізнесу. На ринку сфери послуг виробники туристичних продуктів, в сучасних умовах, мають володіти засобами реалізації результатів своєї діяльності. Саме реклама $є$ найбільш дієвим інструментом доведення інформації до споживача.

В умовах загострення конкуренції реклама $\epsilon$ важливим чинником конкурентної боротьби, що дозволяє впроваджувати технічні інновації та знизити собівартість туристичної послуги.

Туристична реклама - це активний засіб здійснення маркетингової політики туристичної фірми по просуванню туристичного продукту, посиленню зв'язку між виробником і споживачем туристичного продукту.

Для підвищення ефективності діяльності підприємства туристичної індустрії можуть використовувати різні види реклами.

3 постійним розширенням та вдосконаленням інформаційних технологій найбільш популярним видом реклами $\epsilon$ Інтернет-реклама. Вона дозволяє отримувати інформацію про турпродукти на сайтах рекламних площадках, в банерних системах, мережах обміну текстовими 